\title{
Root Parasitism in Exocarpus \\ (with comparative Notes on the Haustoria of Thesium).
}

\author{
BY
}

MARGARET BENSON, D.SC.

With Plate LV and four Figures in the Text.

$\mathrm{D}^{\mathrm{L}}$

URING a visit to Tasmania in 1906 I was much struck by the contrast afforded by the Exocarpus shrubs (chiefly Exocarpus cupressiformis, Lab.)-the 'Native Cherry' of the Australian colonist-and the surrounding vegetation. The summer was exceptionally dry, and the vividly green switch-like habit of these plants made them very conspicuous against the uniformly grey background of the Eucalyptus 'Bush'. In the autumn of the same year (April, 1906), on visiting New South Wales, I was able by the help of my kind host, Mr. William Benson, of Killara, to examine the roots for the parasitic connexions with other plants which I suspected might exist.

We raised a number of young plants and washed the soil carefully away. By this means we were able to demonstrate innumerable connexions with small foreign roots. Some of these were mounted on the spot in glycerine jelly for examination under a low power of the microscope (Text-fig. I). Other young plants were preserved in spirit and dispatched home for histological investigation. A small seedling was sent to me later by Mr. Benson, and has been photographed with some fruiting twigs of an adult tree. This shows the Thesium-like leaves of the young plant, which are progressively smaller on the lateral branches until they become almost entirely suppressed as in the case on the twigs bearing 'Native Cherry' fruits (Pl. LV, Fig. A).

On my return to England I found that Dr. Barber was engaged in describing the haustoria of several Indian genera of Santalaceae and of allied families. ${ }^{1}$

As Exocarpus does not occur in the Indian Flora, it was agreed that I should report on this genus.

1 Barber: The Hanstorium of Santalum album. Memoirs of the Dep. of Agriculture in India, vol. i, No. I, Parts I and II, Jan. I906 and July I907. The Haustorium of Olax Scandens, ibid. vol. ii, No. 4, 1907. Parasitic Trees in Southern India. Proc. of the Cambridge Philosophical Society, vol. xiv, Part III.

[Annals of Botany, Vol. XXIV. No. XCVI. October, 19ro.] 
The haustoria that had been preserved in spirit were therefore cut, and the series of microtome sections carefully stained by my friends, Miss Chambers and Miss Welsford, to whom my thanks are due for making the best of rather hurriedly preserved material. The slides exhibited features in the conducting tissue of the haustorium which had not previously been

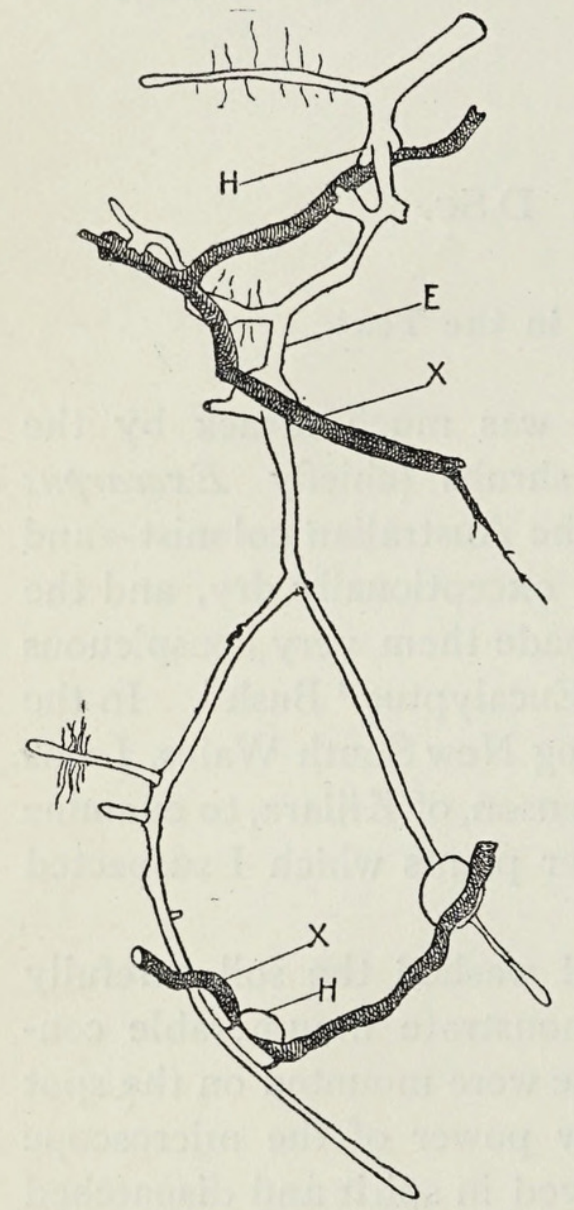

Text-Fig. I. A portion of an Exocarpus root, $E$, attacking two foreign roots by means of variously shaped haustoria, $H . \quad \times 8$.

The foreign roots, $X$, are shaded. The branching of the Exocarpus root is apparently abnormal on either side of the pointer, $E$. laceae. It is much to be regretted that they have been published in memoirs not ordinarily accessible to students. It is only from his own statement that we learn he was hampered in the use of the microtome by the unfavourable climate conditions of Madras.

${ }^{1}$ Heinricher: Cohn's Beiträge z. Biol. d. Pflanzen, B. 7, ii, I895; Pringsheim's Jahrbuch, vol. xxxii, 189 s; Ibid., vol. xxxvi, I901.

${ }^{2}$ Pierce: Annals of Botany, vii, 1893 .

3 Solms-Laubach: Ueber den Bau und die Entwicklung parasitischer Phanerogamen. Pringsheim's Jahrbuch, vol. vi, I867.

4 Barber, 1. c. summer, therefore (August, I909), I collected a large number of the haustoria of Thesium in Canton Valais, Switzerland, for comparison. These were also cut with the microtome and stained in the same way.

The latter preparations have been of great use to me as they have shown clearly that the haustoria of Exocarpus, while agreeing in many particulars, differ in others from those of hitherto described Santalaceae. If I enter into some detail in describing these haustoria it is because no previous description based on microtome serial sections of such structures seems to have been published.

Heinricher's detailed papers ${ }^{1}$ deal with no member of the Santalaceae. Pierce ${ }^{2}$ treats of Cuscuta and other genera whose haustoria are by common consent of different origin from those of the Santalaceae. SolmsLaubach's ${ }^{3}$ valuable monograph was published so long ago as 1867 .

To Dr. Barber's ${ }^{4}$ work on other members of Santalaceae frequent reference will be made. His interesting papers should be consulted by any one who wishes to realize the range of problems involved in the investigation of the parasitic habit of the Santarecorded for Santalaceous haustoria. Last 


\section{General Morphology of the Roots and Haustoria of EXOCARPUS.}

The roots branch very irregularly, and show but an insignificant development of root-hairs (Text-fig. I). They are generally of a red-brown colour.

The haustoria are minute, and occur chiefly on very slender branches, which makes it exceedingly difficult to demonstrate them except in young plants which it is possible to lift with the soil still attached. Those depicted in Fig. A on Pl. LV are but slightly reduced, but it will be found advisable to use a hand lens in examining them. Those drawn in Textfigure I are magnified about 8 diameters. The branches on which the haustoria occur may arise exogenously, and in one case of which I have a serial set of transverse sections the branching was a simple dichotomy. The haustoria are generally, if not always, lateral, two sometimes appearing near the tip of a small root. As recorded by Dr. Barber for other members of Santalaceae, it is generally possible to demonstrate a continuation of the mother root, even though, through a series of many sections, the haustorium appears to be terminal (cp. left-hand haustoria in Text-fig. I).

Anatomically the branches bearing haustoria differ from one another. Some contain irregularly disposed, reticulately thickened tracheides like those in the Thesium haustorium (Fig. 2, Pl. LV, n.). These I will refer to as 'necks', and they will be found invariably to terminate in a haustorium. Others contain a strand of pitted tracheides with phloem, and differ only in the number of protoxylems from the mother root. These always spring from a protoxylem of the mother root, and though often adventitious are obviously best regarded as roots. In the case of equal dichotomy it is impossible to do otherwise. In a third type (that selected for illustration in Text-fig. 2) we see a well-developed haustorium borne on a neck which only differs from an ordinary root in the absence of phloem and in the presence of a terminal haustorium. On the whole it would appear that the roots of Exocarpus are (like those of Thesium) profoundly influenced in their mode of branching by the new functions superposed on that of absorption from the soil. The direction also of the growth, especially of the lateral roots, is affected more by the proximity of their would-be hosts than by their relation to the vertical position.

\section{THe Haustorium.}

Before proceeding to discuss the features of interest in these new haustoria it may be well to explain by the help of the diagram (Text-fig. 2) the terms applied to the various parts of the organ. This diagram represents a transverse section of the Exocarpus root, $E$, with a haustorium 
$H$, cut longitudinally in the median plane. The drawing is constructed from a series of sections stained with safranin and aniline blue. $F$ is the foreign root upon which the haustorium is preying. The neck, $N$, of the haustorium contains reticulately thickened tracheides. These are continuous with the conducting cells of the 'nucleus' of the haustorium. The nucleus is composed of two parts : the central core, $C$, of nucleated transparent cells, and the vascular sheath, $V$, which covers the whole surface of the nucleus and is often many cells thick, especially on the proximal surface, where it

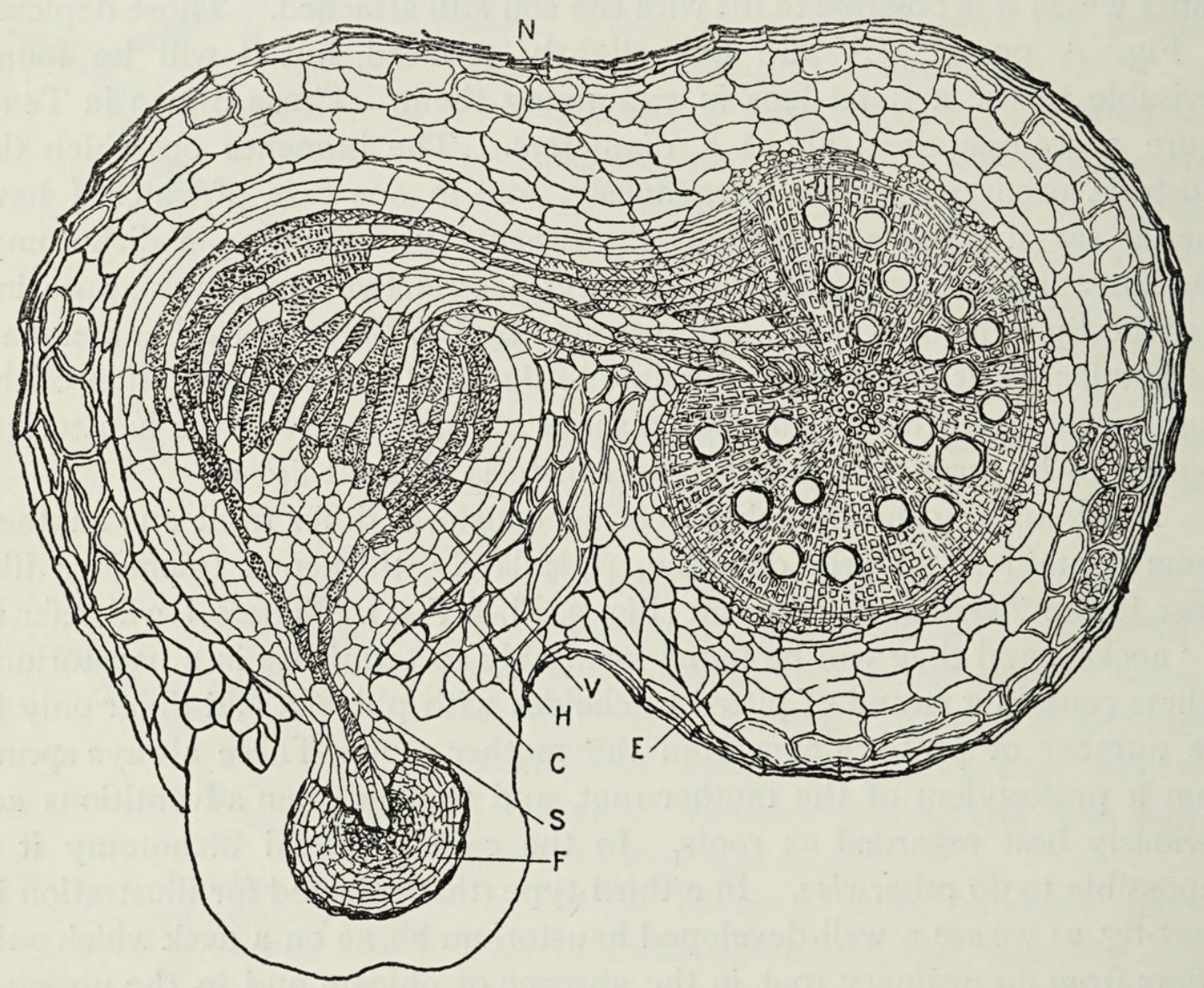

TExT-FIG. 2. An Exocarpus root in transverse section bearing a haustorium with a sucker which has reached to the centre of the stele of a foreign root. The cortex cells of the latter have been omitted for clearness. Starch grains were present in all the cortical cells of the parasite, but have been purposely omitted except in a few cases. Further description in the text. $\times$ I 35.

forms a kind of pad. In the distal part it is continuous with the lignified collecting cells in the sucker, $S$. The vascular elements of the haustorium I propose to refer to under the name of phloeotracheides for reasons which are given later. The walls of the tracheides of the neck and of the phloeotracheides differ from those in the xylem of the mother root in the absence of circular bordered pits (compare Text-figs. $3 a$ and $3 b$ ). The phloeotracheides contain a thin layer of matrix in which are embedded small approximately spherical bodies which stain a bright blue with aniline. As 
the lignified bands on the walls of the cells in which they lie are stained pink with the safranin, the constituent parts of the haustorium are effectively exhibited in the series of sections from which the diagram is constructed.

\section{The Phloeotracheides.}

These cells, the so-called 'vessels' of previous writers on Santalaceous haustoria, are sufficiently unique to merit description.

They appear to be common to all root haustoria, although arranged in several different ways.

In radially symmetrical Exocarpus haustoria they form a flask-shaped sheath to the central hyaline core, the neck of the flask abutting upon the host, and being surrounded by nucleated club-shaped cells which probably have a secretory function.
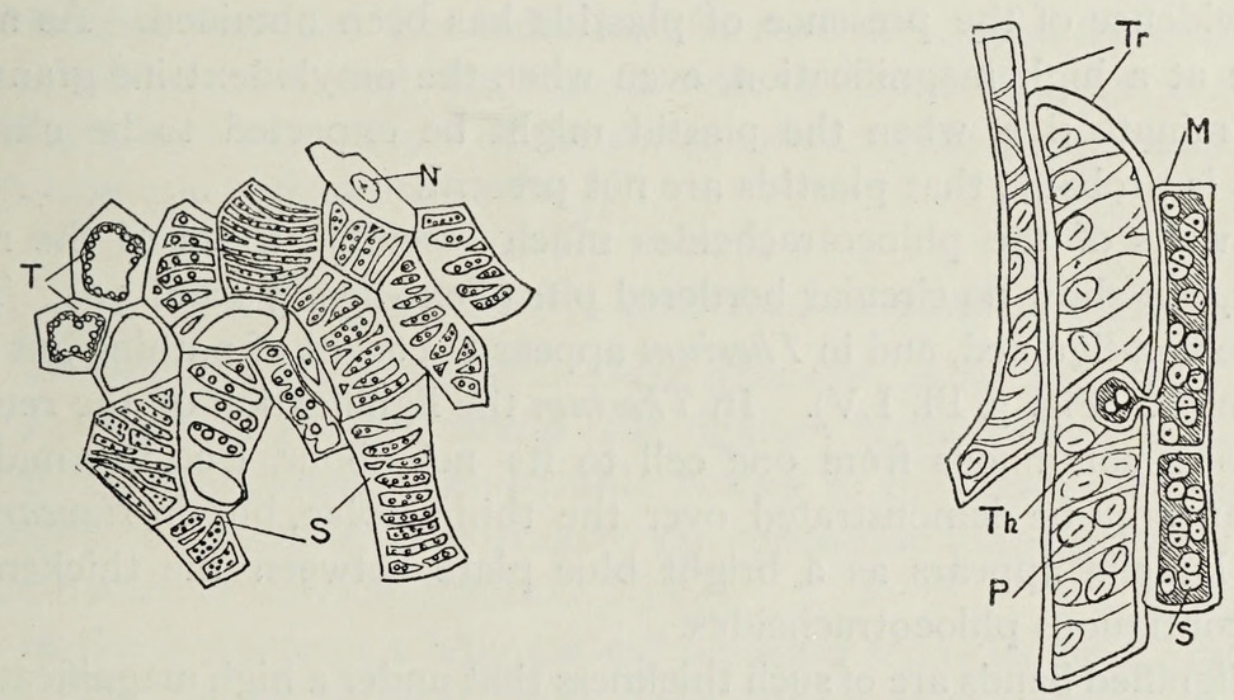

TEXT-FIGS. $3 a$ and $3 b$. Enlarged drawings of parts of an Exocarpus root with haustorium.

Text-Fig. $3 a$. Surface, $S$, and transverse, $T$, sections of the phloeotracheides of a haustorium containing granules of various sizes. $N=$ a nucleated thin-walled cell accompanying the phloeotracheides. $\times 230$.
Text-FIG. 3 b. A longitudinal section of part of the xylem of an Exocarpus root showing two tracheides, $T r$, with bordered pits, $P$. Two medullary ray cells $(M)$ filled with starch grains abut on the tracheides, and one has thrust in a thylosis, $T h$, which also contains starch. $\times 230$.

The phloeotracheides, in all but three cases that have come under my observation, contain granules of a carbohydrate.

Although in some cases these phloeotracheides, when stained with safranin and aniline, bear a superficial resemblance to the sieve-tubes of some Ferns, there is no ground for thinking the pellicles are callose in nature nor that they are continuous through the thin areolae. The explanation of their presence is, probably, that the residual protoplasm of the partially differentiated tracheide receives such an abundant supply of hydrolysed cellulose that part of it is deposited as amylodextrine. 
The important question as to the presence of protoplasm, a nucleus, and plastids in these cells is left an open question by Heinricher (see later, p. 673).

A thin matrix lining the walls is generally demonstrable.

The task of securing evidence as to its nature is a difficult one, but in one series through a Thesium haustorium I have satisfied myself that delicate strands of protoplasm can be seen traversing the lumen, and that these are continuous with the matrix in which the granules are embedded (Fig. 3, Pl. LV).

It is much easier to obtain evidence as to the absence of nuclei, for those of the surrounding cells take up a staining reagent which is not taken up by the cytoplasm. Thus it can be shown again and again that the thinwalled, non-lignified cells interspersed among the phloeotracheides contain nuclei, but that nuclei do not occur in the lignified phloeotracheides.

No evidence of the presence of plastids has been obtained. As none are visible at a high magnification, even when the amylodextrine granules are very minute (i. e. when the plastid might be expected to be clearly visible), it is probable that plastids are not present.

The walls of the phloeotracheides much resemble those of the root tracheides, but show no circular bordered pits (Text-figs. $3 a$ and $3 b$ ). The areolae are non-lignified, and in Thesium appear to consist of nothing but the middle lamella (Fig. 3, Pl. LV). In Thesium the lignification of the reticulate bands is continuous from one cell to its neighbour, i. e. the middle lamella can only be demonstrated over the thin areolae, but in Exocarpus a middle lamella appears as a bright blue plate between the thickening bands of contiguous phloeotracheides.

The lignified bands are of such thickness that under a high magnification the granules appear to be disposed only over the thin areolae, but with transverse sections it is easy to show that the granules are uniformly distributed over the inner surface of the cell.

By means of a series of longitudinal sections of the haustorium of Exocarpus one can demonstrate that the sheath of these cells is much thicker on the proximal surface of the 'nucleus ', i.e. there is a continuous mass of lignified cells lying between the transparent central cells of the nucleus and the neck of the haustorium. A series of sections also shows that there is continuity between this pad and the tracheides of the neck, but I have not been able to demonstrate the presence of the blue staining granules in any cells but those of the sheath.

Cells apparently of the same character are found reaching down to the surface of absorption from the host. There is no reason to regard them as secretory. They are found to be surrounded, at the surface of contact with the host, by tubular, thin-walled nucleated cells, and hence appear to be primarily of importance as conducting cells. None the less, the apices, as 
has been described by Leclerc du Sablon ${ }^{1}$ for the apices of such cells in Rhinanthaceous haustoria, are often non-striated and thin-walled. I have noted what I believe is a nucleus in one apex, and there can be no doubt as to their apical growth.

Fig. 3, Pl. LV, shows the apical part of one of these cells abutting on the starch-containing cells of a medullary ray of the host root.

If we take all these facts into consideration and remember that no true phloem occurs in the haustoria of any so far described root parasite, we realize that these cells have a complex nature.

They collect and act as the pathway for the hydrolysed products of solution of the host cells and deposit in their lumina granules differing from those occurring elsewhere in the root. They are lined with protoplasm, but contain no nucleus, and in these respects resemble sieve-tubes.

They are, however, lignified, and it has been possible in many cases to demonstrate that their end walls are absorbed as in open tracheides.

It will be convenient, therefore, to refer to these cells as phloeotracheides, for they afford an example of the combination of the structure and function of phloem and xylem elements.

\section{The Granules in the Phloeotracheides.}

The only previous record of these granules, as far as I know, is due to Heinricher, ${ }^{2}$ who made a careful investigation of the chemical and physical properties of apparently comparable bodies in the conducting cells of the haustoria of Lathraea. He came to the conclusion that they were probably of the nature of amylodextrine.

In the footnote of a later paper ${ }^{3}$ he again refers to these granules, and states that Wegler believes them to be present in the haustoria of all the Rhinanthaceae. Heinricher uses the expression, 'die Tracheidenreihen häufig mit Amylodextrinstärke erfüllt sind.' He found also the amylodextrine bodies in smaller amount in the cells of the parenchyma of the tracheide head. In Exocarpus when granules occur elsewhere than in the phloeotracheides they are starch granules, and are not stained by the aniline. The grains, however, are much smaller than those of the cortical cells.

The amylodextrine bodies abut so closely on the wall that I am inclined to regard them as occasionally deposited upon the inner surface. One of the most remarkable things about them is their early appearance in cells only just cut off from the meristem. They seem to appear simultaneously with the lignification of the wall. Their size bears a rough relation to the width of the bands of thickening in any given cell. Thus

${ }^{1}$ Leclerc du Sablon: Organes d'absorption des plantes parasites. Annales des Sci. Nat., 7 th series, vol. vi, Pl. II.

${ }^{2}$ Heinricher, Cohn's Beiträge, Band 7,1895 , p. 344 ; also Pl. IX, Fig. 7.

3 Heinricher, Die griinen Halbschmarotzer. Pringsheim's Jahrbuch, 190I, iii, p. 725. 
where the bands are fine the pellicles are often numerous but minute, and in a neighbouring cell where the bands are broad the pellicles may be uniseriate and relatively large. This phenomenon rather points against a dependence of their formation on plastids (Text-fig. $3 a$ ).

\section{Connexion of the Haustoria with the Mother Root.}

In Exocarpus and Thesium, one of the most striking features of many of these haustoria is the somewhat abrupt change in character which is noticeable when one passes from the phloeotracheides to the tracheides of the neck. The neck tracheides contain no matrix and no granules. They are often scattered, so that in certain sections of a series there may be no continuity between them and the phloeotracheides.

It may be useful to note that neither in Exocarpus nor in Thesium have I observed any disintegration of the conducting cells of the haustoria such as Dr. Barber describes ${ }^{1}$ as occasionally occurring in Santalum. Continuity is established, as Solms-Laubach ${ }^{2}$ described for Thesium, by reticulately thickened tracheides-' einzelne vielfach zickzackförmige Gefässreihen die Verbindung der Gefässbögen mit dem Bündel der Mutterwurzel bewerkstelligen.' But in Exocarpus the phloeotracheides are not limited to two bands ('Gefässbögen') as in Thesium. It would be along the tracheides of the neck that the first water-supply must come to the developing haustorium, and it is with the xylem that they are continuous.

\section{COMPARISON OF THE HAUSTORIA OF EXOCARPUS WITH THOSE OF THEsIUm.}

The Thesium haustorium, like those of all other members of Santalaceae hitherto described, shows the phloeotracheides in two bands instead of being distributed all over the surface of the nucleus as in Exocarpus. Also there is no pad of phloeotracheides at the proximal end of the haustorium. The granules are present in the phloeotracheides (Fig. 3, Pl. LV), but are far smaller and less regular than in Exocarpus. In both genera the phloeotracheides may or may not be regularly formed from a meristem.

\section{Thesium as a Host.}

In three series which had ostensibly been taken through haustoria of Thesium it was found that Thesium was the host. In one case the attack had been made by another Thesium root, and in the other two cases by haustoria of another type (Fig. I, Pl. LV). I have not been able to identify the form, but it is obviously built on the plan of those of the

${ }^{1}$ Barber, 1. c., Santalum album, Part II, p. 20 (and also Plates III and IX, I2). Proc. of Camb. Phil. Soc., vol. xiv, Part III, p. ${ }^{2} 5^{2}$.

Solms-Laubach, 1. c., p. 544 . 
Rhinanthaceae. ${ }^{1}$ The phloeotracheides form a head and an axile strand, while the translucent cells which are axile in Santalaceous haustoria surround the axile strand. Thus all the same types of cell are present, but are distributed differently.

Fig. 2, Pl. LV, exhibits a section through a Thesium root attacked by another Thesium root. The haustorium is borne laterally on a small diarch root and shows the apparently interrupted continuity between the haustorium and the mother root. It is noticeable that the surface of contact between parasite and host is scarcely distinguishable. For this cause the cells of the cortex are not entered in the drawing. Fig. $2 a$ is an enlarged drawing of part of the cells abutting on one another, and no trace of disintegrated cell-wall is visible. This case is in harmony with an observation made by Dr. Barber of a comparable case in Santalum. Dr. Barber ${ }^{2}$ noted that when Santalum haustoria had become fixed to the roots of Santalum actual fusion of the tissues seemed to occur, and pointed out that it would appear to be more or less natural that such fusions should occur.

Such cases suggest that when a Thesium root attacks one of its own kind a state of equilibrium is reached, and possibly both roots share the supplies. Opposed, however, to this view is the fact that only a trace of starch is to be seen in the medullary rays of the host root, although in other cases the Thesium root is charged with starch. Moreover, Barber describes an interesting case in which a Santalum root, when undergoing self-attack, had proceeded to occlude the region affected and make some effort to throttle the sucker.

\section{Discussion as to the Function OF the HAUSTORIA.}

In one series of sections the sucker of a Thesium haustorium has penetrated and split into two halves the stele of a grass root, and is shown in the act of absorbing the thickening layers on the wall of the further part of the endodermis. This and many other sections suggestive of the same thing show us that the haustoria of these hemiparasites do not limit themselves to an attack on the water-carrying elements. I mention this because it seems rather overlooked in the literature. Thus Haberlandt ${ }^{3}$ says of the absorbing cells: 'Sie setzen sich auf kürzestem Wege mit den Gefässen der Nahrwurzel in Verbindung.'

Solms-Laubach ${ }^{4}$ also, while figuring only such cases of root parasitism as do not penetrate beyond the wood, says :--'Der Saugfortsatz ist genöthigt, die sehr feste Schutzscheide und das Holz zu spalten, um seine Gefässe denen der Graswurzel anlegen zu können.'

Such expressions, though true, are liable to be misunderstood, for there

${ }^{1}$ Cf. Solms-Laubach, 1. c., Taf. XXXIV; also Leclerc du Sablon, 1. c.

${ }^{2}$ Barber, l. c., Santalum album, Pt. II, p. 44.

${ }^{3}$ Haberlandt, Pflanzenanatomie, 3. Auflage, 1904, p. 225.

4 Solms-Laubach, 1.c., p. 549; also Tafel XXXII, Fig. 4. 
can be no doubt that the haustoria do more than just tap the water-supply of foreign roots. Even animal organisms can be dissolved and absorbed. ${ }^{1}$ Exocarpus, indeed, more frequently than not wholly dissolves and absorbs the portion of the host root attacked. A vigorous attack on the host is likely to give the most abundant supply, and we find that all kinds of cells, except perhaps cork, yield to the attack.

It is in the light of these observations that possibly we may find the significance of the granules in the phloeotracheides. Heinricher ${ }^{2}$ refers to the structures as 'storage tracheides'. But in such a case as Exocarpus, which under normal circumstances is exposed to drought conditions combined with much insolation, one cannot but look on these masses of cells interposed between the host and the mother root as serving as a filter. The granules by their precipitation leave the ascending sap less charged with dissolved carbohydrate, which is already present in excess in cortex and medullary rays.

The different habit of Thesium, which is abundant on the moist Alps of Switzerland, may account for the insignificant development of granules in its phloeotracheides.

Not only is the period of vegetative activity much shorter, but the host plants would be much richer in watery sap.

\section{SumMary.}

On the roots of various plants of Exocarpus, chiefly Exocarpus cupressiformis, Lab., growing in the Bush near Killara, N.S.W., were found innumerable haustoria which varied much in size and form.

Their anatomy was examined and compared with that of Thesium haustoria gathered in August in Switzerland.

The haustoria contained a large proportion of lignified tissue which was composed of elements for which the name 'phloeotracheides' is suggested. The tissue was not limited to two bands as is the case in the haustoria so far described of other Santalaceae. The function of these cells is discussed, and the probability advanced that they may be of service as a filter.

I should like to take this opportunity of acknowledging my indebtedness to Mr. Maiden, of the Botanical Gardens, Sydney, N.S.W., who was most helpful to me in various ways during my residence in that neighbourhood.

${ }^{1}$ Cf. Barber's Chrysalis, 1. c., Santalum album, Part I, par. 9, and Figs. I5-I 7 , Pl. III.

${ }^{2}$ Heinricher, 1.c., 1901, p. 725 , footnote. 


\title{
DESCRIPTION OF THE FIGURES IN PLATE LV.
}

\author{
Illustrating Dr. Margaret Benson's paper on Exocarpus.
}

Figures A and I-3.

Fig. A. A seedling plant of Exocarpus cupressiformis, showing the form of the early leaves, which decrease in size on the lateral branches. The roots show many haustoria, which are indicated by the letter $H$. F $F$ represents a foreign root to which the Exocarpus root is attached. To the right of the seedling are some twigs from an adult plant showing the switch-like habit and the 'Native Cherry' fruits. (Slightly reduced.)

Fig. I. A camera drawing of a Rhinanthaceous haustorium upon a Thesium root. Th= the Thesium root; $H=$ the haustorium attached to the neck, $N$. No granules were present in the phloeotracheide head, $P h$. Note the axile row of phloeotracheides continuous from the head to the surface of contact with the host. $\times 87$.

Fig. 2. A camera drawing of a Thesium haustorium, $H$, attached to a Thesium root, $T h$. The neck, $N$, shows continuity by means of short tracheides with the diarch Thesium root, $R$. The surface of contact is only faintly distinguishable owing to the almost complete fusion of the two structures. $\times 87$.

Fig. $2 a$. An enlarged drawing of the left-hand phloeotracheide of the above figure, showing its insertion into a medullary ray of the host. $M=$ the medullary ray cell containing starch grains; $\operatorname{Tr}=$ a tracheide of the host root ; $P h=$ the phloeotracheide with its non-striated tip inserted into the ray. $\times 345$.

Fig. 3. An enlarged drawing of an ordinary phloeotracheide from a haustorium of Thesium. Strands which are thought to be protoplasm are seen in continuity with the living matrix, which contains spherical granules, $G$, of amylodextrine. Two thin-walled, nucleated cells, $N$, abut on the phloeotracheide. $\times 345$. 


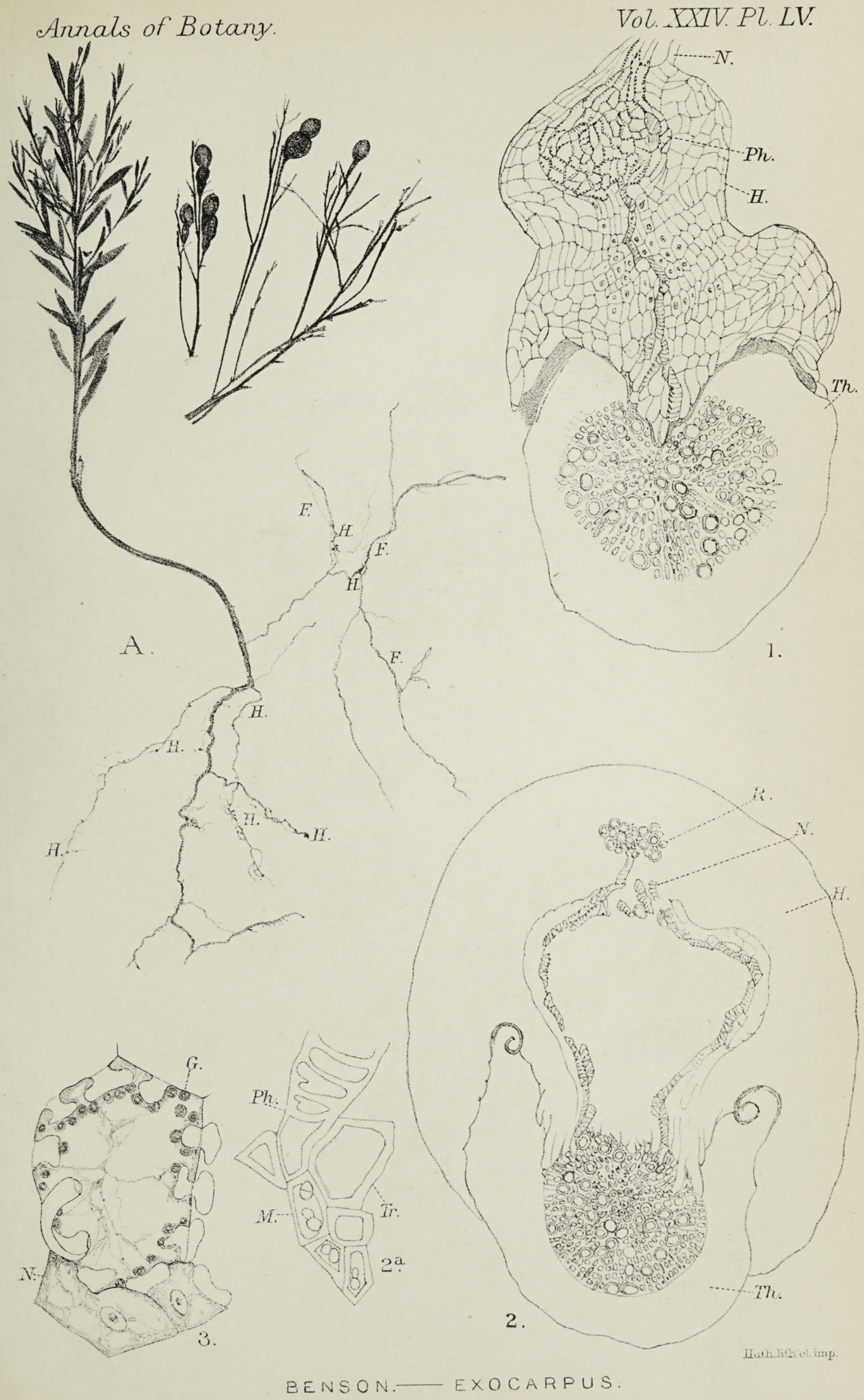




\section{$2 \mathrm{BHL}$ Biodiversity Heritage Library}

Benson, Margaret. 1910. "Root parasitism in Exocarpus (with comparative notes on the haustoria of Thesium)." Annals of botany 24, 667-677. https://doi.org/10.1093/oxfordjournals.aob.a089297.

View This Item Online: https://www.biodiversitylibrary.org/item/262605

DOI: https://doi.org/10.1093/oxfordjournals.aob.a089297

Permalink: https://www.biodiversitylibrary.org/partpdf/319805

\section{Holding Institution}

New York Botanical Garden, LuEsther T. Mertz Library

\section{Sponsored by}

BHL-SIL-FEDLINK

\section{Copyright \& Reuse}

Copyright Status: Public domain. The BHL considers that this work is no longer under copyright protection.

This document was created from content at the Biodiversity Heritage Library, the world's largest open access digital library for biodiversity literature and archives. Visit BHL at https://www.biodiversitylibrary.org. 